\title{
Effect of Intraperitoneal Etanercept on Oxidative Stress in Rats with Peritonitis
}

\author{
Yasar Yildirim, ${ }^{1}$ Esma Gulsum Cellad, ${ }^{2}$ Ali Veysel Kara, ${ }^{1}$ \\ Zülfükar Yilmaz, ${ }^{1}$ Ali Kemal Kadiroglu, ${ }^{1}$ Mehmet Veysi Bahadir, ${ }^{3}$ Mesut Gul, ${ }^{3}$ \\ Muzaffer Aydin Ketani, ${ }^{4}$ and Mehmet Emin Yilmaz ${ }^{1}$
}

\author{
${ }^{1}$ Department of Nephology, Dicle University Faculty of Medicine, 21090 Diyarbakir, Turkey \\ ${ }^{2}$ Department of Internal Medicine, Dicle University Faculty of Medicine, 21090 Diyarbakir, Turkey \\ ${ }^{3}$ Department of General Surgery, Dicle University Faculty of Medicine, 21090 Diyarbakir, Turkey \\ ${ }^{4}$ Department of Histology and Embryology, Dicle University Faculty of Veterinary Medicine, Turkey
}

Correspondence should be addressed to Yasar Yildirim; yyil11@yahoo.com

Received 25 December 2015; Accepted 23 February 2016

Academic Editor: Ryuichi Morishita

Copyright (C) 2016 Yasar Yildirim et al. This is an open access article distributed under the Creative Commons Attribution License, which permits unrestricted use, distribution, and reproduction in any medium, provided the original work is properly cited.

\begin{abstract}
Our aim was to evaluate effect of etanercept on oxidative stress parameters in rats with experimental peritonitis and investigate the availability of etanercept usage in the treatment of peritonitis in the future. Twenty-eight rats were divided into four groups as control (group 1), peritonitis (group 2), peritonitis + cefazolin sodium (group 3), and peritonitis + cefazolin sodium + etanercept (group 4). Peritoneal tissue and blood samples were taken from all of the rats for histopathological and biochemical examination. The oxidative stress parameters were examined in blood and tissue samples. It was observed that rats with peritonitis benefit from cefazolin sodium treatment. Evaluating the effectiveness of etanercept was our main objective for this study. In this perspective, we compared group 3 and group 4 and found statistically significant decreases in oxidative parameters and statistically significant increases in antioxidants in serum and tissue samples in group 4. It is observed that there was a significant contribution of etanercept on biochemical and also histopathological results. As a result, the TNF- $\alpha$ inhibitor, etanercept, in addition to antibiotics given in the early treatment of peritonitis results in more significant improvement of histopathological and oxidative parameters as compared to antibiotics alone.
\end{abstract}

\section{Introduction}

Peritonitis, which is the inflammation of the peritoneal tissue, can cause systemic inflammatory response and sepsis. This most likely occurs because infectious agents can pass rapidly from the peritoneal surface to circulation [1]. Peritoneal sepsis is a clinical entity with high rates of morbidity and mortality. Therefore, limiting peritonitis in early stages is of paramount importance. In fact, proinflammatory cytokines such as TNF- $\alpha$ and IL-1 are increased as a part of the inflammatory response in order to limit tissue damage [2]. However, overproduction of proinflammatory cytokines disrupts the normal immune response and causes a pathological response. As a result, capillary leakage, tissue damage, and multiorgan failure can occur. TNF- $\alpha$ plays an important role in this process and is considered as the main mediator in the early stage of inflammation [3]. Etanercept is the competitive inhibitor of TNF- $\alpha$ which inhibits the binding of TNF- $\alpha$ to cell surface receptors and limits its biological activity. Suppression of TNF- $\alpha$ by etanercept in the case of excessive immune response can play an important role in the limiting of inflammation [4]. Inflammation causes oxidative stress which often results in decreased antioxidant levels and increased production of oxidant. The presence of oxidative stress is an important parameter which can be measured to indicate tissue damage.

\section{Material and Methods}

Our experimental study was conducted in Dicle University by Professor Dr. Sabahattin Payzin at the Health Science Research and Application Center (DUSAM) with 
TABLE 1: Histopathological scoring system for the tissue evaluation.

\begin{tabular}{lcccc}
\hline Absent & Minimal & Weak & Moderate & Strong \\
\hline 0 & 1 & 2 & 3 & 4 \\
\hline
\end{tabular}

the approval of ethical committee for animal experiments. The project was supported by Dicle University Coordination of Scientific Research Projects (project number 13-TF-34). A total of 28 adult female Wistar Albino rats weighing between 200 and $250 \mathrm{~g}$ were used and fed with standard chow and water prior to the experiment.

Twenty-eight rats were divided into four groups $(n=7$ per group) as follows:

Group 1: control group, in which rats did not receive any drugs.

Group 2: peritonitis group, in which intraperitoneal injection of $1.5 \mathrm{~mL}$ Escherichia coli suspension $(107 \mathrm{CFU} / \mathrm{mL})$ was made to cause experimental peritonitis.

Group 3: peritonitis + cephazolin sodium group, in which intraperitoneal cephazolin sodium injection (50 mg/kg) was made one hour after the injection of E. coli suspension.

Group 4: peritonitis + cephazolin sodium + etanercept group, in which intraperitoneal cephazolin sodium injection was made one hour after the injection of E. coli suspension ( $50 \mathrm{mg} / \mathrm{kg}$ ). Also intraperitoneal etanercept injection was made one and four hours after the injection of $E$. coli suspension. The study was terminated 24 hours after the etanercept injection.

Ketamine hydrochloride $(70 \mathrm{mg} / \mathrm{kg}$ ) was administered intramuscularly (im) to rats before surgery. Rats under anesthesia were fixed at the supine position. Midline incision of the anterior abdominal wall was performed on all of the rats for histopathological and biochemical examination. Full thickness tissues except skin with $1 \mathrm{~cm}$ of length and $3 \mathrm{~mm}$ of thickness were taken from left half and right half of the midline abdominal wall, respectively, for biochemical and histopathological examination. Tissue samples for histopathological examination were fixed in $10.0 \%$ buffered formalin. Tissue samples for biochemical examination were taken into the aluminum foil. Then, sternotomy was made and $5 \mathrm{~mL}$ blood sample was taken from the heart. Also, with this method, killing of the animals was achieved.

2.1. Biochemical Analysis. Blood was centrifuged at $5,000 \mathrm{rpm}$ and $4^{\circ} \mathrm{C}$ for 8 minutes and supernatants were collected for study. Tissue samples were placed in refrigerator at $-20^{\circ} \mathrm{C}$ until homogenized. Tissue homogenization was performed using a homogenizer in the laboratory. After that, paraoxonase (PON), malondialdehyde (MDA), nitric oxide (NO), total antioxidant capacity (TAC), total oxidant stress (TOS), and tumor necrosis factor alpha (TNF- $\alpha$ ) were studied from tissue and blood samples in the biochemical laboratory of Dicle University.

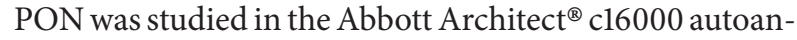
alyzer by using RL0031 Rel Assay ${ }^{\circledR}$ Diagnostics Paraoxonase (Gaziantep, turkey) kit. NWLSS (Northwest Life Science Specialties) Malondialdehyde Assay kit was used for malondialdehyde and reading was made at $450 \mathrm{~nm}$ by Dynex micro ELISA device. Cayman Chemical Company 780001 Nitrite Colorimetric Assay kit was used for NO and reading was made at between $540 \mathrm{~nm}$ and $550 \mathrm{~nm}$ by Dynex micro ELISA device. TAC was studied in in the Abbott Architect ${ }^{\circledR}$ c16000 autoanalyzer by using RL0017Rel Assay ${ }^{\circledR}$ Diagnostics TAS kit (Gaziantep, Turkey). TOS was studied in the Abbott Architect $^{\circledR}$ c16000 autoanalyzer by using RL0024 Rel Assay ${ }^{\circledR}$ Diagnostics (Gaziantep, Turkey) TOS Assay kit. TAC AND TOS were studied by the method of Erel. Serum levels of TNF- $\alpha$ were measured by Biosource Rat TNF- $\alpha$ kit (lot number KRC3011), which is a solid phase sandwich enzyme linked immune sorbent assay (ELISA).

2.2. Histopathological Analysis. Paraffin sections of 4-5micrometer thickness were taken from tissue samples by using rotary microtome. These sections were stained with hematoxylin and eosin ( $\mathrm{H} \& \mathrm{E})$ and examined by the Nikon Eclipse 400 digital camera (Nikon DSRi). Peritoneal epithelial shedding (desquamation), congestion in the lamina propria, neutrophil infiltration in the lamina propria, and edema in the lamina propria were evaluated histopathologically and scored from 0 to 4 (Table 1 ).

2.3. Statistical Analysis. Data analyses were performed using Statistical Package for Social Sciences (SPSS), Version 16.0 for Windows. All the data are presented as mean \pm standard error. Kruskal-Wallis test was used to analyze multiple groups and Mann-Whitney $U$ test was used for binary comparison of groups. $p<0.05$ was considered statistically significant.

\section{Results}

We found statistically significant differences between group 1 and group 2 in terms of oxidative parameters and antioxidants in the serum and peritoneal tissue. There were an increase in oxidative parameters and a decrease in antioxidants in group 2 according to group 1. When we compared group 2 and group 3, there was a statistically significant decrease in the oxidative parameters (MDA, TOS, and TNF$\alpha$ ) in serum and tissue samples in group 2 , whereas there was a statistically significant increase in the antioxidant parameters (TAC, PON) in serum and tissue sample in group 3 (Table 2). However, there was no statistically significant difference between groups in terms of NO in serum $(p=0.090)$ and the tissue samples $(p=0.264)$. Evaluating the effectiveness of etanercept was our main aim in this study. In this perspective, we compared group 3 and group 4 and found statistically 
TABLE 2: Comparison of serum and tissue oxidant and antioxidant parameters.

\begin{tabular}{|c|c|c|c|c|}
\hline Parameters & $\begin{array}{l}\text { Group } 1 \\
(n=7)\end{array}$ & $\begin{array}{c}\text { Group } 2 \\
(n=7)\end{array}$ & $\begin{array}{c}\text { Group } 3 \\
(n=7)\end{array}$ & $\begin{array}{c}\text { Group } 4 \\
(n=7)\end{array}$ \\
\hline \multicolumn{5}{|l|}{ Serum } \\
\hline MDA (mmol/mL) & $0.73 \pm 0.17$ & $1.67 \pm 0.32^{\mathrm{d}}$ & $1.28 \pm 0.21^{\mathrm{b}}$ & $0.90 \pm 0.26^{\mathrm{c}, \mathrm{e}}$ \\
\hline $\operatorname{TOS}(\mu \mathrm{mol} / \mathrm{L})$ & $33.59 \pm 11.23$ & $80.30 \pm 11.26^{\mathrm{d}}$ & $52.73 \pm 12.48^{c}$ & $39.07 \pm 7.07^{\mathrm{c}, \mathrm{e}}$ \\
\hline $\mathrm{NO}(\mu \mathrm{M} / \mathrm{L})$ & $4.85 \pm 0.39$ & $5.80 \pm 0.46^{\mathrm{a}}$ & $5.41 \pm 0.32^{c}$ & $4.90 \pm 0.32^{\mathrm{b}, \mathrm{c}}$ \\
\hline TNF- $\alpha(\mathrm{pg} / \mathrm{mL})$ & $2.72 \pm 1.45$ & $18.50 \pm 10.01^{\mathrm{a}}$ & $9.01 \pm 2.06^{\mathrm{b}}$ & $5.77 \pm 2.34^{\mathrm{b}, \mathrm{c}}$ \\
\hline $\mathrm{TAC}(\mathrm{mmol} / \mathrm{L})$ & $1.32 \pm 0.10$ & $0.87 \pm 0.30^{\mathrm{a}}$ & $1.18 \pm 0.10^{\mathrm{b}}$ & $1.56 \pm 0.11^{\mathrm{e}, \mathrm{f}}$ \\
\hline PON (U/L) & $197.03 \pm 37.63$ & $124.61 \pm 15.81^{\mathrm{a}}$ & $145.67 \pm 7.75^{b}$ & $157.70 \pm 10.25^{\mathrm{b}, \mathrm{c}}$ \\
\hline \multicolumn{5}{|l|}{ Peritoneal tissue } \\
\hline MDA (mmol/mL) & $0.12 \pm 0.25$ & $1.31 \pm 0.41^{\mathrm{d}}$ & $0.59 \pm 0.35^{\mathrm{b}}$ & $0.12 \pm 0.07^{\mathrm{c}, \mathrm{e}}$ \\
\hline $\operatorname{TOS}(\mu \mathrm{mol} / \mathrm{L})$ & $7.16 \pm 3.53$ & $45.90 \pm 26.57^{\mathrm{a}}$ & $14.18 \pm 4.58^{\mathrm{b}}$ & $8.77 \pm 4.11^{\mathrm{b}, \mathrm{c}}$ \\
\hline $\mathrm{NO}(\mu \mathrm{M} / \mathrm{L})$ & $3.95 \pm 0.87$ & $6.65 \pm 1.36^{\mathrm{a}}$ & $6.00 \pm 0.52$ & $5.29 \pm 0.22^{\mathrm{b}, \mathrm{c}}$ \\
\hline TNF- $\alpha(p g / m L)$ & $116.39 \pm 42.36$ & $487.21 \pm 238.44^{\mathrm{a}}$ & $265.22 \pm 52.74^{\mathrm{b}}$ & $136.83 \pm 24.26^{\mathrm{b}, \mathrm{f}}$ \\
\hline $\mathrm{TAC}(\mathrm{mmol} / \mathrm{L})$ & $0.80 \pm 0.11$ & $0.34 \pm 0.08^{\mathrm{d}}$ & $0.47 \pm 0.064^{\mathrm{b}}$ & $0.66 \pm 0.14^{\mathrm{c}, \mathrm{e}}$ \\
\hline PON (U/L) & $12.74 \pm 3.32$ & $1.83 \pm 2.54^{\mathrm{d}}$ & $4.82 \pm 1.37^{\mathrm{b}}$ & $8.34 \pm 1.14^{\mathrm{e}, \mathrm{f}}$ \\
\hline
\end{tabular}

MDA: malondialdehyde, NO: nitric oxide, TNF- $\alpha$ : tumor necrosis factor alpha, TAC: total antioxidant capacity, TOS: total oxidant stress, and PON: paraoxonase.

${ }^{\mathrm{a}} p<0.005$ as compared to group $1,{ }^{\mathrm{b}} p<0.005$ as compared to group $2,{ }^{\mathrm{c}} p<0.005$ as compared to group $3,{ }^{\mathrm{d}} p<0.001$ as compared to group 1 , ${ }^{\mathrm{e}} p<0.001$ as compared to group 2 , and ${ }^{\mathrm{f}} p<0.001$ as compared to group 3 .
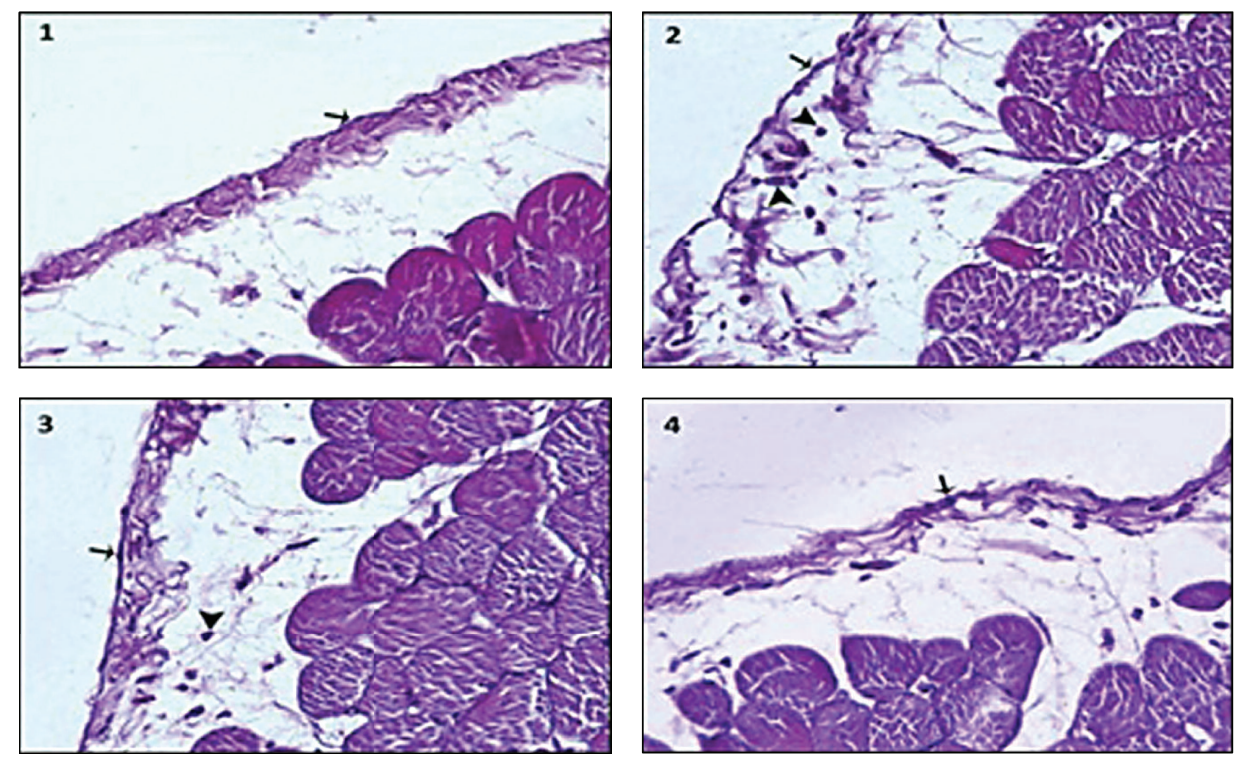

FIGURE 1: Microscopic findings of the parietal peritoneum in groups ((1) control group, (2) peritonitis group, (3) peritonitis + cephazolin sodium group, and (4) peritonitis + cephazolin sodium + etanercept group).

significant decreases in oxidative parameters (MDA, TNF- $\alpha$, TOS, and NO) in serum and tissue samples and statistically significant increases in antioxidants (TAC, PON) in serum and tissue samples in group 4 (Table 2). These results were more prominent in comparison of group 2 and group 4 .

Microscopic findings of parietal peritonitis in the groups were shown in Figure 1. In our study, we also found that there were no histopathological changes in peritoneal epithelium and lamina propria in group 1. In group 2, there were peritoneal epithelial shedding, diffuse neutrophil infiltration and edema in the lamina propria, and congestion in capillary vessels. We observed that there was a statistically significant reduction in peritoneal epithelium shedding $(p<0.01)$, edema ( $p<0.01)$, congestion, and neutrophil infiltration in the lamina propria $(p<0.01)$ in group 3 compared to group 2 due to effect of cephazolin sodium (Table 3 ). In group 4, in which we used etanercept, there was a statistically significant reduction in the epithelial shedding, congestion, edema, and neutrophil infiltration in the lamina propria according to both group 2 (resp., $p<0.01, p<0.01$, and $p<0.001$ ) and 
TABLE 3: Histopathological results.

\begin{tabular}{|c|c|c|c|c|}
\hline $\begin{array}{l}\text { Histopathological } \\
\text { results }\end{array}$ & Control group (group 1) & Peritonitis group (group 2) & $\begin{array}{l}\text { Peritonitis + cephazolin } \\
\text { sodium group (group 3) }\end{array}$ & $\begin{array}{c}\text { Peritonitis + cephazolin } \\
\text { sodium + etanercept group } \\
\text { (group 4) }\end{array}$ \\
\hline $\begin{array}{l}\text { Peritoneal epithelial } \\
\text { shedding } \\
\text { (desquamation) }\end{array}$ & $0.0 \pm 0.0$ & $3.71 \pm 0.48^{\mathrm{a}}$ & $2.71 \pm 0.48^{c}$ & $1.0 \pm 0.57^{\text {c.e }}$ \\
\hline Congestion & $0.0 \pm 0.0$ & $4.0 \pm 0.0^{\mathrm{b}}$ & $2.42 \pm 0.78^{\mathrm{c}}$ & $1.28 \pm 0.48^{\text {c.f }}$ \\
\hline $\begin{array}{l}\text { Neutrophil } \\
\text { infiltration }\end{array}$ & $0.0 \pm 0.0$ & $4.0 \pm 0.0^{\mathrm{b}}$ & $2.28 \pm 0.48^{\mathrm{c}}$ & $1.14 \pm 0.37^{\text {d.e }}$ \\
\hline Edema & $0.0 \pm 0.0$ & $3.71 \pm 0.48^{\mathrm{a}}$ & $1.85 \pm 0.69^{c}$ & $1.14 \pm 0.37^{\text {c.f }}$ \\
\hline
\end{tabular}

${ }^{\mathrm{a}} p<0.01$ as compared to group $1,{ }^{\mathrm{b}} p<0.001$ as compared to group $1,{ }^{\mathrm{c}} p<0.01$ as compared to group $2,{ }^{\mathrm{d}} p<0.001$ as compared to group 2 , ${ }^{\mathrm{e}} p<0.01$ as compared to group 3 , and ${ }^{\mathrm{f}} p<0.05$ as compared to group 3 .

group 3 (resp., $p<0.01, p<0.05$, and $p<0.01$ ). There were statistically significant differences between groups in terms of histopathological results (Table 3).

\section{Discussion}

Peritonitis is the inflammation of visceral or parietal peritoneum. It can cause systemic inflammatory response and sepsis if not treated properly. It is still one of the significant causes of morbidity and mortality worldwide despite improvements of treatment methods, intensive care unit conditions, and intensive care units devices. Peritonitis is not a simple infection process; inflammation and immunological dysregulation are activated by different mechanisms and can lead to multiple organ failure. Therefore, peritonitis is an important clinical table, which can cause multiple organ failure. Limiting this process in stage of peritonitis is crucial. It is thought that there are some unexplained pathologic mechanisms in this process and therefore experimental models are needed.

Peritoneal membrane is semipermeable and has an advanced ability of secretion and absorption. If urea, fluids with electrolytes, drugs, and infective material are given to peritoneal cavity, they can rapidly pass to systemic circulation. Therefore, peritonitis models in experimental animal studies are valuable for creating sepsis and they are closest designs to human sepsis.

Inflammation is an important part in the formation of sepsis. Proinflammatory cytokines such as TNF- $\alpha$ and IL1 were secreted to limit tissue damage. However, overproduction of proinflammatory cytokines disturbs the normal order of immune response and can lead to a pathological inflammatory response. This situation results in capillary leakage, tissue damage, and multiple organ failure [3]. TNF$\alpha$ plays an important role in the inflammation process and is considered a master mediator of early stage inflammation. Guo et al. found that TNF- $\alpha$ levels were highest in the early period after injection $(30 \mathrm{~min}-1 \mathrm{~h})$ in a sepsis model elicited lipopolysaccharide injection [5]. Etanercept is the competitive inhibitor of TNF- $\alpha$, which inhibits the binding of TNF- $\alpha$ to cell surface receptors and limits its biological activity. Suppression of TNF- $\alpha$ by etanercept in the case of excessive immune response can play an important role in the limiting of inflammation. Karabacak and Yazar predicted clinical benefit [6] and surveillance may also improve [5].

Release of oxygen particles due to infectious and immunological causes can alter the lipid, protein, and DNA structure of cells and results in cell damage and death [7, 8]. In addition to this, antioxidants are also released to protect against harmful effects of oxidants. Stable and sufficient function of this system is important to deal with harmful effects of oxidative stress [9].

According to these pieces of information, we created an experimental peritonitis model in the rats, and we injected intraperitoneal etanercept in early stage to suppress inflammation. We aimed to show the effects of intraperitoneal etanercept on oxidant and antioxidant parameters. Therefore, we also indirectly investigated effect of etanercept on preventing oxidative damage in sepsis and peritonitis clinics. We created peritonitis in the rats by injection of $1.5 \mathrm{~mL}(107 \mathrm{CFU} / \mathrm{mL})$ E. coli suspension, followed by dividing them into 4 groups: group 1, control group; group 2, peritonitis group; group 3, peritonitis + cephazolin sodium group; group 4, peritonitis + cephazolin sodium + etanercept group.

Antibiotics play a main role in the treatment of infectious peritonitis. Therefore, many researchers have compared the effectiveness of various antibiotics in peritonitis $[10,11]$. In our study, the use of cephazolin sodium as effective antibiotic in the treatment of peritonitis was preferred [10]. Intraperitoneal cephazolin sodium in a dose of $50 \mathrm{mg} / \mathrm{kg}$ was given to groups 3 and 4 one hour after the injection of $E$. coli suspension. There are many clinical studies made by antibiotics or antibiotics and other drugs combinations to limit peritonitis such as antibiotic + vitamin E [12], antibiotics + normobaric oxygen therapy [13], and antibiotics + oxygen-free radicals scavengers [14]. It can be seen that etanercept has been used for suppression of inflammation in autoimmune diseases such as rheumatoid arthritis [15], ankylosing spondylitis [16], psoriatic arthritis [17], and psoriasis vulgaris [18]. We also observed that etanercept has been used experimentally in the nonautoimmune disease. It was shown that etanercept can improve neuroinflammation and myocardial ischemia reperfusion injury $[19,20]$.

It is known that TNF- $\alpha$ is responsible for early responses of inflammation, which was secreted minutes after the inflammatory stimulus, peaked at first hour, and stopped after 
3-4 h [21]. Therefore, we injected etanercept at first hour and TNF- $\alpha$ peaked at the 4 th hour when secretion of TNF- $\alpha$ stopped. We injected etanercept in a dose of $8 \mathrm{mg} / \mathrm{kg}$ which is not toxic but can block TNF- $\alpha[22,23]$. We basically compared these two treatment methods by looking to serum and tissue levels of MDA, NO, TNF- $\alpha$, TOS, TAC, and PON. We evaluated the histopathological findings in all groups. An increase in levels of MDA, TNF- $\alpha$, and TOS shows oxidative stress and an increase in levels of TAC and PON shows antioxidant activity. Upon a literature search, we found that NO has been shown to be cytoprotective at low levels and cytotoxic at high levels unlike the other parameters [24].

If we correlate the histopathological findings with the oxidant and antioxidant parameters variability in serum and tissue samples, we can conclude that addition of etanercept to cephazolin sodium treatment in early stages of peritonitis treatment can be useful for limiting the peritonitis. Increased suppression of TNF- $\alpha$ levels with the usage of etanercept seems to be useful for limiting peritonitis. In a study by Chen et al., they found decreased antioxidant levels in rats with subacute peritonitis compared with the control group [25]. Similar to this study, we also found decreased antioxidant levels. Di Paola et al. showed an increase in TNF- $\alpha$ levels in infected tissues of rats with periodontitis compared with control group [26]. We also found an increase in TNF- $\alpha$ levels in groups with peritonitis compared with control group (TNF- $\alpha$ levels in group 1: $116.39 \pm 42.36 \mathrm{pg} / \mathrm{mL}$ and TNF$\alpha$ levels in group 2: $487.21 \pm 238.44 \mathrm{pg} / \mathrm{mL}, p=0.002)$. A decrease in TNF- $\alpha$ levels by using etanercept in the same study was also seen in group 4 in our study (TNF- $\alpha$ levels in group 4: $136.83 \pm 24.26)$. We also showed a statistically significant decrease in MDA levels in serum $(p<0.001)$ and tissue samples $(p<0.001)$ in group 4 compared with group 2 similar to decrease in MDA levels by using etanercept in the study [26]. A decrease in TNF- $\alpha$ and MDA by using etanercept was collocated with histopathological improvement. We found increased NO levels in peritonitis group similar to previous reports [27]. In our study, there were statistically significant differences between group 1 and group 2 in terms of NO levels in serum $(p=0.001)$ and tissue samples $(p=0.001)$. Unlike other parameters, there was a statistically nonsignificant decrease in NO levels in group 3. In group 4, there were statistically significant decreases in NO levels. PON, which is a powerful antioxidant, decreases in case of infection $[28,29]$. There was a statistically significant difference between group 1 and group 2 in terms of serum $(p=0.001)$ and tissue $(p<0.001)$ for PON levels. PON levels were decreased in peritoneal tissue $(1.83 \pm 2.54 \mathrm{U} / \mathrm{L})$ and serum $(124.61 \pm 15.81 \mathrm{U} / \mathrm{L})$ in rats with peritonitis. With the addition of the treatment, there was an increase in PON levels in serum and tissue samples in group 3 and group 4. This increase was prominent in group 4 in terms of both serum $(p=0.029)$ and tissue samples $(p<0.001)$.

Consistent with the literature, there was a decrease in oxidative parameters and an increase in antioxidant levels by using etanercept in addition to cephazolin sodium in rats with experimental peritonitis. A decrease in the edema, congestion, and neutrophil infiltration in the lamina propria of the peritoneum was another important finding of this study. It appears that the suppression of TNF- $\alpha$ in early stage can reduce excessive immune response resulting in the destruction of the organism.

As a result, etanercept, in addition to antibiotics given in the early treatment of peritonitis, results in more significant improvement in histopathological and oxidative parameters according to antibiotics alone. We believe that etanercept can decrease sepsis incidence in peritonitis but there is a need for more comprehensive experimental studies for usage in the treatment of peritonitis.

\section{Competing Interests}

The authors declare that they have no competing interests.

\section{Acknowledgments}

The authors experimental study was conducted in Dicle University by Professor Dr. Sabahattin Payzın at the Health Science Research and Application Center (DUSAM) with the approval of ethical committee for animal experiments. The project was supported by Dicle University Coordination of Scientific Research Projects (Project no. 13-TF-34).

\section{References}

[1] K. Gülçin, "Peritonit ve Sepsis modelleri," Turkiye Klinikleri Journal of Nephrology-Special Topics, vol. 3, no. 3, pp. 41-45, 2010.

[2] L. Ulloa and K. J. Tracey, "The cytokine profile: a code for sepsis," Trends in Molecular Medicine, vol. 11, no. 2, pp. 56-63, 2005.

[3] T. A. Burçin, D. Avlan, A. Polat, L. Tamer, K. Büyükafşar, and S. Aksöyek, "The effect of inhibition of high mobility group box-1 and tumor necrosis factor alpha on intestinal morphology and motility in rats with peritonitis," Çocuk Cerrahisi Dergisi, vol. 22, no. 1, pp. 15-24, 2008.

[4] M. Taban, W. Dupps, B. Mandell, and V. Perez, "Etanercept (Enbrel)-associated inflammatory eye disease: case report and review of the literature," Ocular Immunology and Inflammation, vol. 14, no. 3, pp. 145-150, 2006.

[5] Z. Guo, S. Wang, Q. Jiao, M. Xu, and Z. Xu, "Soluble TNFR II/IgG1 Fc fusion protein treatment in the LPS-mediated septic shock of rats," Biomedicine and Pharmacotherapy, vol. 63, no. 7, pp. 537-542, 2009.

[6] A. Karabacak and E. Yazar, "Current approaches in the treatment of septic shock," Eurasian Journal of Veterinary Sciences, vol. 22, pp. 95-103, 2006.

[7] C. G. Cochrone, "Cellular injur by oxidants," The American Journal of Medicine, vol. 91, no. 3, pp. 23S-30S, 1991.

[8] S. Fujii, G. L. Dale, and E. Beutler, "Glutathione-dependent protection against oxidative damage of the human red cell membrane," Blood, vol. 63, no. 5, pp. 1096-1101, 1984.

[9] Y. M. Betül and A. Sami, "Oksidatif Stress ve antioksidanlar," Erciyes Üniversitesi Sağlık Bilimleri Dergisi, vol. 9, no. 1, pp. 49$53,2000$.

[10] A. Çelık and T. Çamsari, "CAPD perıtonıtlerı ve tedavısı,” Türk Nefroloji Diyaliz ve Transplantasyon Dergisi, vol. 3, pp. 1-4, 1994.

[11] Z. Adıbelli and A. T. Peritonitis, Turk Nefroloji Diyaliz ve Transplantasyon Dergisi, vol. 14, no. 2, pp. 45-51, 2007. 
[12] D. Shrivastava, P. Gharde, D. Sharma, R. K. Jain, D. B. Sharma, and A. Saxena, "Effect of vitamin $\mathrm{E}$ as an adjuvant to metronidazole in experimental model of peritonitis," International Journal of Biomedical And Advance Research, vol. 4, no. 12, pp. 1-6, 2013.

[13] T. Yücel, D. Gönüllü, S. Güçlü et al., "Normobarik oksijenin deneysel peritonitin tedavisindeki yeri ve tedavinin izlenmesinde rektal ateş, lökosit, CRP ve prokalsitoninin etkinliği," Ulusal Travma ve Acil Cerrahi Derneği, vol. 14, no. 1, pp. 14-20, 2008.

[14] S. Gökgöz, C. Yıldırır, and G. Ersoy, "Deneysel peritonit tedavisinde antibiyotikler, serbest oksijen radikal gidericiler ve kombinasyonlarının rolü," T Klin Gastroenterophepatoloji, vol. 6, no. 2, pp. 71-75, 1995.

[15] X. Ma and S. Xu, "TNF inhibitor therapy for rheumatoid arthritis," Biomedical Reports, vol. 1, no. 2, pp. 177-184, 2013.

[16] G. Kalı, Y. Ersoy, B. Durmuş, Z. Altay, Ö. Baysal, and Y. Ersoy, "Ankilozan spondilitli hastalarda etanercept tedavisinin etkinliğ ve güvenilirliği," Inönü Üniversitesi Tıp Fakültesi Dergisi, vol. 17, no. 2, pp. 91-96, 2010.

[17] E. Çapkın, M. Karkucak, G. Özden, M. Tosun, and H. Çakırbay, "Dirençli psöriatik artritli bir olguda etanercept tedavisi," Nobel Medicus 19, vol. 7, no. 1, pp. 112-114, 2011.

[18] C. L. Leonardi, J. L. Powers, R. T. Matheson et al., "Etanercept as monotherapy in patients with psoriasis," The New England Journal of Medicine, vol. 349, no. 21, pp. 2014-2022, 2003.

[19] J. Ye, R. Jiang, M. Cui et al., "Etanercept reduces neuroinflammation and lethality in mouse model of Japanese encephalitis," Journal of Infectious Diseases, vol. 210, no. 6, pp. 875-889, 2014.

[20] M. Yang, J. Chen, J. Zhao, and M. Meng, "Etanercept attenuates myocardial ischemia/reperfusion injury by decreasing inflammation and oxidative stress," PLoS ONE, vol. 9, no. 9, Article ID e108024, 2014.

[21] H. Wang, H. Yang, C. J. Czura, A. E. Sama, and K. J. Tracey, "HMBG1 as a late mediator of lethal systemic inflammation," American Journal of Respiratory and Critical Care Medicine, vol. 164, no. 10, part 1, pp. 1768-1773, 2001.

[22] A. Geier, G. Zollner, C. G. Dietrich et al., "Cytokineindependent repression of rodent Ntcp in obstructive cholestasis," Hepatology, vol. 41, no. 3, pp. 470-477, 2005.

[23] M. Roderfeld, A. Geier, C. G. Dietrich et al., "Cytokine blockade inhibits hepatic tissue inhibitor of metalloproteinase-1 expression and up-regulates matrix metalloproteinase- 9 in toxic liver injury," Liver International, vol. 26, no. 5, pp. 579-586, 2006.

[24] M. Demir, I. Kaleli, S. Demir et al., "Liver lipid peroxidation in experimental Escherichia coli peritonitis: the role of myeloperoxidase and nitric oxide inhibition," Medical Science Monitor, vol. 13, no. 10, pp. BR225-BR229, 2007.

[25] Y.-H. Chen, C.-H. Lee, C.-C. Hsiao, L.-S. Hsu, and H.-C. Lo, "Diverse effects of parenteral arginine on systemic and local oxidant-antioxidant homeostasis and nitrosative stress in rats with subacute peritonitis," Journal of Surgical Research, vol. 187, no. 1, pp. 134-141, 2014.

[26] R. Di Paola, E. Mazzon, C. Muià et al., "Effects of etanercept, a tumour necrosis factor- $\alpha$ antagonist, in an experimental model of periodontitis in rats," British Journal of Pharmacology, vol. 150, no. 3, pp. 286-297, 2007.

[27] I. M. J. Oudenhoven, H. L. B. M. Klaasen, J. A. Lapré, A. H. Weerkamp, and R. Van Der Meer, "Nitric oxide-derived urinary nitrate as a marker of intestinal bacterial translocation in rats," Gastroenterology, vol. 107, no. 1, pp. 47-53, 1994.
[28] Y. Li, R. Zhai, H. Li, X. Mei, and G. Qiu, "Prognostic value of serum paraoxonase and arylesterase activity in patients with sepsis," Journal of International Medical Research, vol. 41, no. 3, pp. 681-687, 2013.

[29] S. Tekin Koruk, N. Aksoy, M. Hamidanoglu, H. Karsen, S. Unlu, and H. Bilinc, "The activity of paraoxonase and arylesterase in patients with osteomyelitis," Scandinavian Journal of Clinical and Laboratory Investigation, vol. 72, no. 7, pp. 513-517, 2012. 


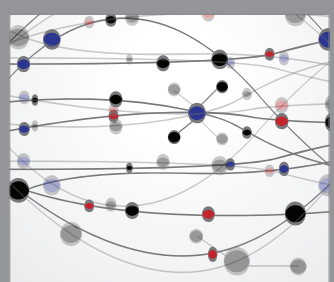

The Scientific World Journal
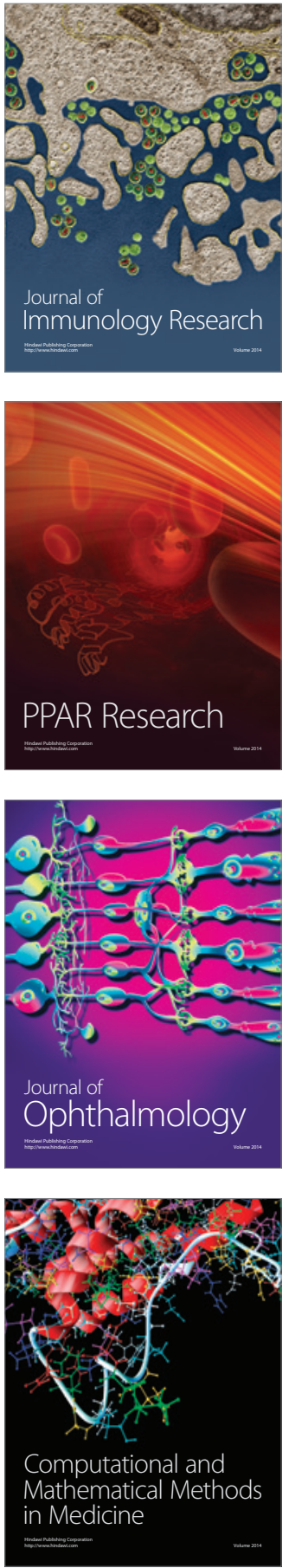

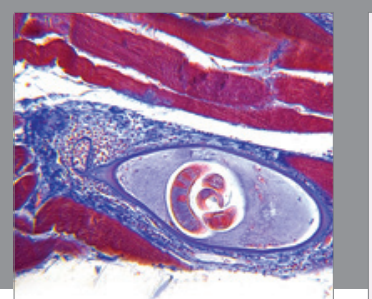

Gastroenterology Research and Practice

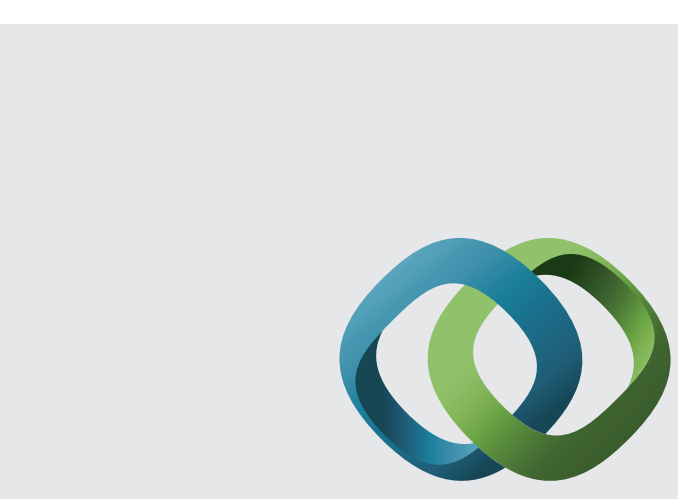

\section{Hindawi}

Submit your manuscripts at

http://www.hindawi.com
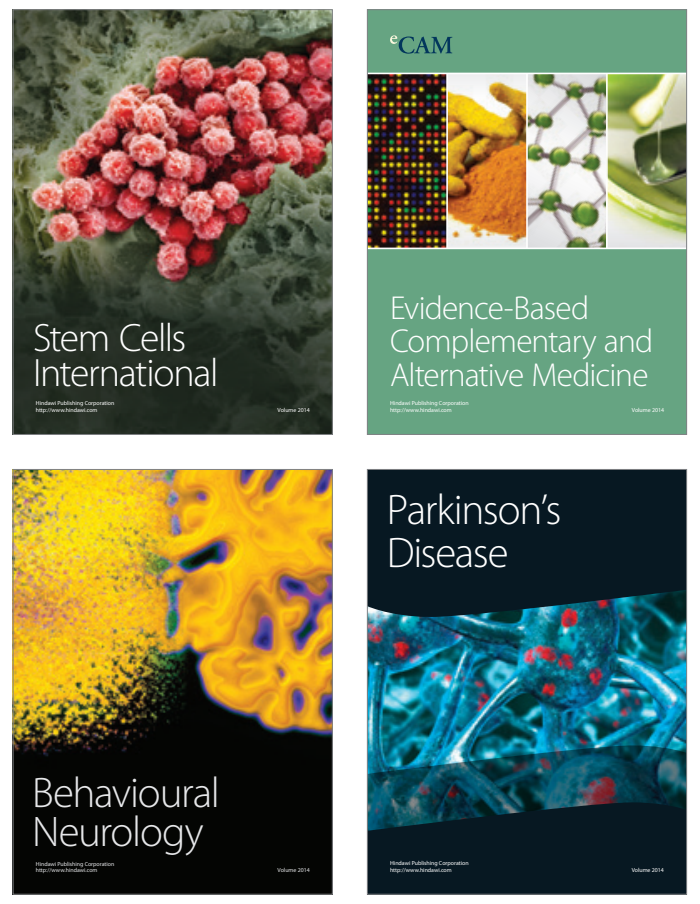
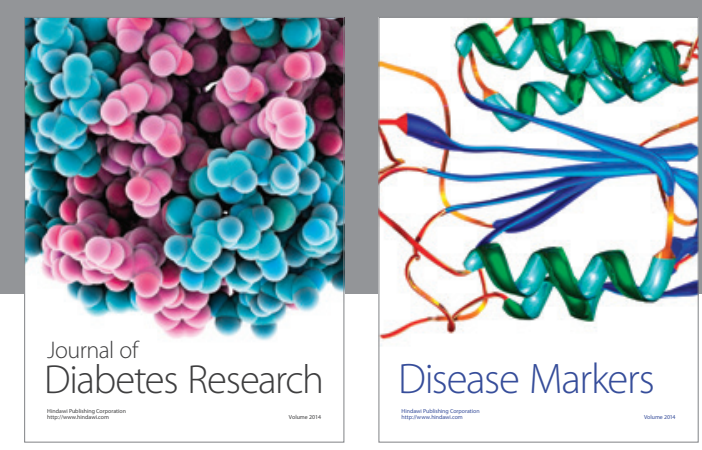

Disease Markers
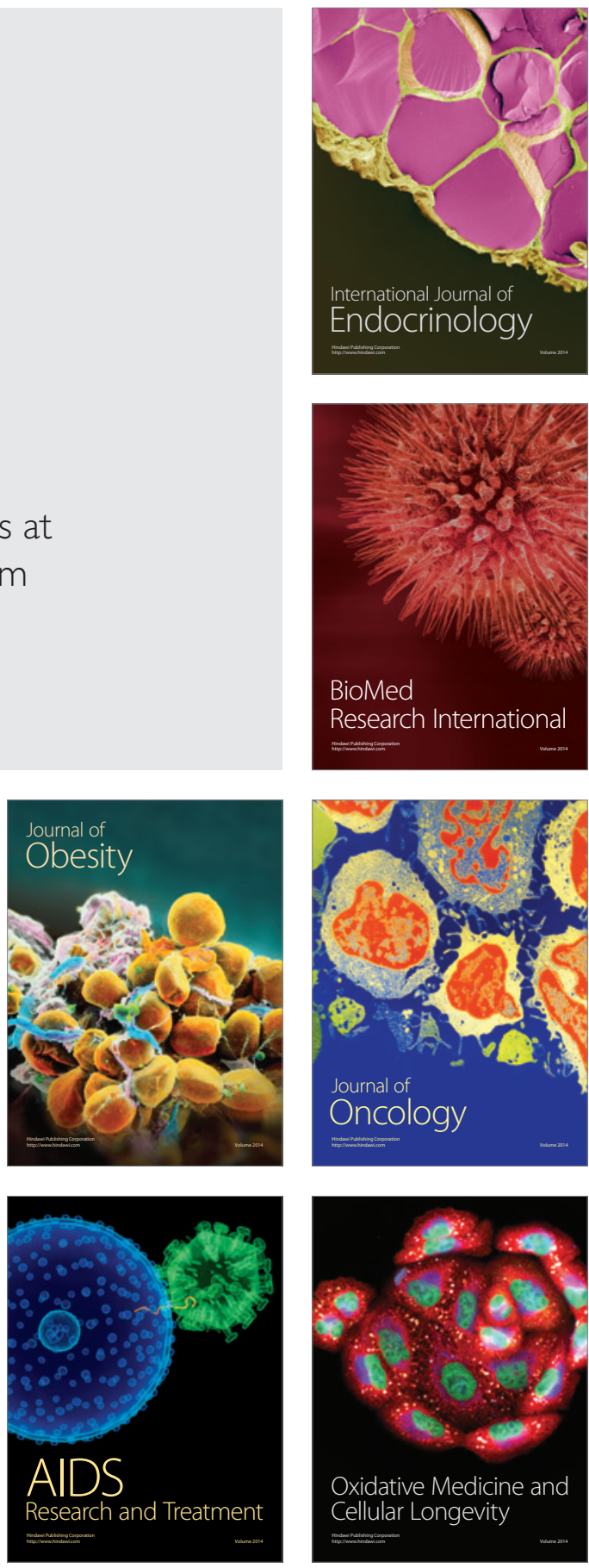